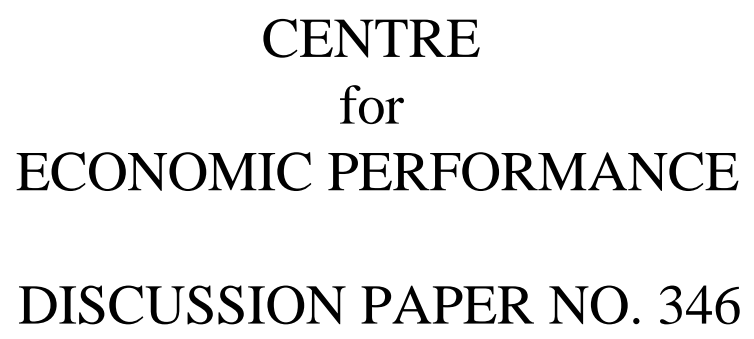

May 1997

PITFALLS IN THE THEORY OF INTERNATIONAL TRADE POLICY: CONCERTINA REFORMS OF TARIFFS AND SUBSIDIES TO HIGH-TECHNOLOGY INDUSTRIES

J. P. Neary 


\begin{abstract}
This paper explores the links between international trade theory and the practice of trade and industrial policy in open economies, with special attention to three areas where theoretical lessons have been misunderstood in policy debates. I argue that the 'concertina rule' for tariff reform justifies reductions in high tariffs, but not moves towards uniformity, and particularly not increases in low tariffs. I show that the basic principles of tariff reform are the same in unilateral, multilateral and customs union contexts. Finally, I show that the theory of strategic trade policy does not justify export subsidies to high-technology industries.
\end{abstract}

This paper was produced as part of the Centre's International Economic Performance Programme 


\title{
PITFALLS IN THE THEORY OF INTERNATIONAL TRADE POLICY: CONCERTINA REFORMS OF TARIFFS AND SUBSIDIES TO HIGH-TECHNOLOGY INDUSTRIES
}

\author{
J. Peter Neary
}




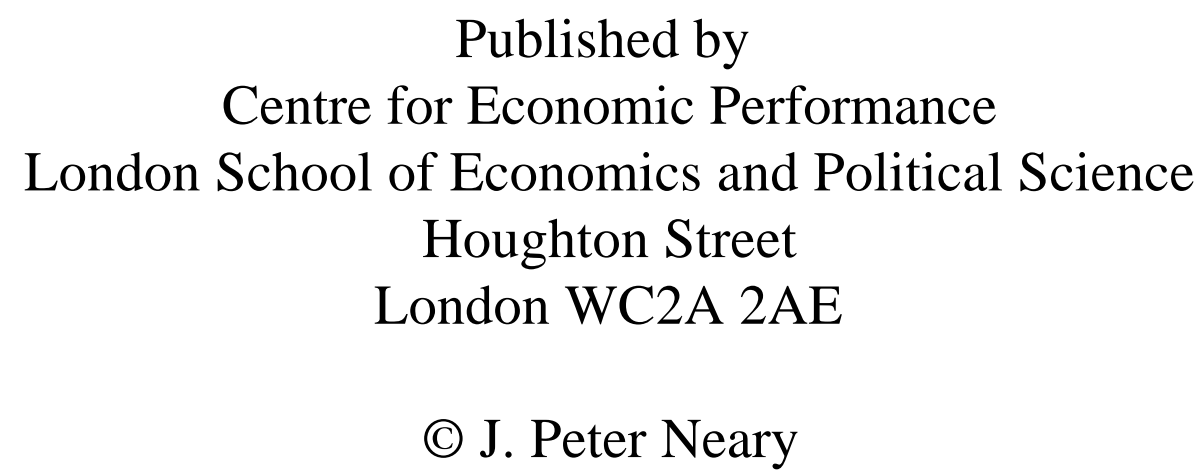

ISBN 0853283591 


\title{
PITFALLS IN THE THEORY OF INTERNATIONAL TRADE POLICY: CONCERTINA REFORMS OF TARIFFS AND SUBSIDIES TO HIGH-TECHNOLOGY INDUSTRIES
}

\author{
J. Peter Neary
}

Page

1. TARIFF REFORM IN A SMALL OPEN ECONOMY

1.1 Tariff Reform in a Small Open Economy with no Numeraire Good

1.2 Tariff Reform in a Small Open Economy without a Numeraire

1.3 Why 'POMPs' are POM

2. UNILATERAL VERSUS MULTILATERAL REFORM OF TRADE POLICY

3. SUBSIDIES TO HIGH TECHNOLOGY FIRMS

3.1 The Optimal Export Subsidy in a One-Period Duopoly

3.2 Optimal Subsidies to R\&D

3.3 R\&D Spillovers and the Case for Industrial Policy

4. SUMMARY AND CONCLUSION

Endnotes

References

The Centre for Economic Performance is financed by the Economic and Social Research Council. Financial support from the CEP/Business Forum is gratefully acknowledged. 


\section{ACKNOWLEDGEMENTS}

This paper was begun during a stimulating visit to the Chinese University of Hong Kong and a preliminary draft was prepared for a Conference on Public Policy and Economic Theory, Oslo, Norway, 31 JanuaryS2 February, 1997. For helpful comments I am grateful to participants at seminars in Florence (EUI), Hong Kong and Mainz. Section 3 draws heavily on my joint work with Dermot Leahy.

J. Peter Neary is a Research Associate at the Centre for Economic Performance and Professor of Political Economy at University College Dublin. 


\section{PITFALLS IN THE THEORY OF INTERNATIONAL TRADE POLICY: CONCERTINA REFORMS OF TARIFFS AND SUBSIDIES TO HIGH-TECHNOLOGY INDUSTRIES}

\section{J. Peter Neary}

Among the many difficulties of economic policy-making is the need to understand the relevant economic theory. In this paper I want to illustrate the delicate and subtle steps from theory to policy advice by means of some examples from recent work in international trade. To set the scene, let me start with three policy questions:

1. What kinds of tariff change will raise welfare in a small open economy?

2. Should countries liberalise trade unilaterally or only multilaterally?

3. Should export-oriented high-technology firms be subsidised?

I think it is self-evident that these questions are important and interesting. They arise in many real-world contexts and non-economists care about the answers. By contrast, consider the following three theoretical questions:

1. Should models of tariff reform contain a numeraire good?

2. How many distinct theorems of tariff reform are there?

3. What should we assume about the relative commitment powers of governments and firms?

Clearly, these are not questions which would ever occur to a noneconomist. I suspect that even many economists would find them dry and uninteresting. Their focus on the literature rather than on the real world suggests that only specialists, and pedantic ones at that, are likely to care about the answers.

Yet, as I hope to show, the answers to the three theoretical questions above are intimately bound up with the answers which our current knowledge allows us to offer to the three policy questions. Moreover, I believe that misunderstandings of the theoretical subtleties involved have 
led some economists to give misleading, if not downright wrong, policy recommendations. I say 'misunderstandings' rather than 'errors' because as a profession we are well trained in rooting out analytic mistakes and there are none such in the literature I review below. However, we may be less sensitised to appreciating the qualifications which need to be made in applying theoretical results. I illustrate this point in each of the following three sections by highlighting statements in the literature which are at best redundant and at worst highly questionable.

\section{TARIFF REFORM IN A SMALL OPEN ECONOMY}

The first topic I consider is that of tariff reform in a perfectly competitive economy which cannot influence its external prices. The main results in this area are well-known since the work of Hatta (1977) and others. In the absence of externalities or 'non-economic' motives for protection, such a small open economy should not restrict trade. Moreover, with given initial tariffs there are two types of change which are guaranteed to raise welfare. One is a uniform radial reduction of tariffs; the other is a 'concertina' reform, which compresses the tariff structure. The concertina reform rule is subject to a well-known qualification: to guarantee a welfare improvement, any good whose tariff is altered must be a net substitute for all other goods. Nevertheless, it is widely advocated in practice and is often used by the World Bank and others to justify tariff reforms which reduce the variance of the tariff structure, lowering exceptionally high and (especially if the reform is required to be revenueneutral) raising exceptionally low tariffs.

Exactly how well-founded in theory are these policy recommendations? To examine this I need to review the theory of tariff reform. Before doing so, I want to note three results which have been derived in the literature in models without a numeraire good. These results are correct as stated but I will argue later that they are not very helpful in policy contexts. So, I label them 'POMPs' for 'Potentially Misleading Propositions'! They are: 
POMP 1: (Diewert, Turunen-Red and Woodland (1989)) A tariff change of the form $d t=d p * ! e t, d+e>0$, must raise welfare.

Here $\mathrm{t}$ and $\mathrm{p}^{*}$ are vectors of specific tariffs and world prices of all goods (including the numeraire) while $d$ and e are scalars. Hence POMP 1 states that welfare will rise if tariffs are increased in proportion to world prices or decreased in proportion to their initial levels.

POMP 2: (Diewert et al (1989)) There always exists some increase in tariffs which will raise welfare.

This is really a corollary of POMP 1 , with e set equal to zero, so the tariff change takes the form $d t=d p^{*}>0$.

POMP 3: (Hatta (1977) Fukushima and Hatta (1989)) An increase in the lowest tariff rate will raise welfare, provided the good in question is a net substitute for all other goods.

This completes my list of POMPs. In order to substantiate my criticisms of them, I need first to present the basic theory of tariff reform. ${ }^{1}$

\subsection{Tariff Reform in a Small Open Economy with no Numeraire Good}

I consider a small open economy which consumes and produces $n+1$ goods which it trades at fixed world prices. For the present, I will assume that there is a numeraire good and denote by $p$ and $p^{*}$ the $n$-by-one vectors of the domestic and world prices of non-numeraire goods respectively. It turns out to be very convenient to summarise the behaviour of consumers and firms in terms of a single function. Following Neary and Schweinberger (1986) I call this the trade expenditure function, defined as the difference between consumer spending and GNP. These in turn are equal to standard expenditure and GNP functions 
respectively:

$$
E(p, u) \quad / \quad e(p, u) \& g(p)
$$

This function embodies a number of assumptions: consumer spending is the outcome of a single utility-maximising individual's decisions; and all goods and factor markets are perfectly competitive with no barriers to efficient intersectoral factor movements. These assumptions are standard but still heroic. They can be justified as allowing a clear focus on the contribution of trade policy to efficiency. The great convenience of the trade expenditure function is that its price derivatives equal the economy's compensated net import demand functions:

$$
E_{p}(p, u) \quad ' \quad e_{p}(p, u) \& g_{p}(p) \quad ' \quad m(p, u)
$$

(This follows because, by Shephard's and Hotelling's Lemmas, $e_{p}$ and $g_{p}$ equal the economy's consumption and output vectors, respectively.) Moreover, these import demand functions are well-behaved: the substitution matrix $S / ! E_{p p}=! m_{p}$ may be assumed to be positive definite. ${ }^{2}$ Finally, the utility derivatives of the trade expenditure function equal those of the household expenditure function. Thus, $E_{u}=e_{u}$, the marginal cost of utility, which it is convenient to normalise to equal one initially; and $E_{p l} / E_{u}=x_{I}$, the vector of Marshallian income derivatives.

We are now ready to summarise the equilibrium of a tariff-distorted small open economy. First, domestic prices equal world prices plus tariffs (by definition there is no tariff on the numeraire good ' 0 ', so $p_{0}=p_{0}^{*}=1$ ):

$$
p \quad p^{(\% t}
$$

Second, since all tariff revenue is redistributed costlessly, it equals net spending by the private sector:

$$
E(p, u) \quad ' \quad t^{\prime} m
$$

where a prime denotes the transpose of a vector or matrix and where net 
imports equal excess demand, from (2). Totally differentiating these equations we obtain the basic expression for the welfare effects of tariff changes in a small open economy:

$$
\left(1 \& t^{\prime} x_{I}\right) d u \quad, \quad \& t^{t} S d t
$$

The coefficient of welfare change on the left-hand side may reasonably be assumed to be positive. ${ }^{3}$ Hence our concern is with the right-hand side of (5).

The uniform reduction result follows immediately. Since $S$ is positive definite, a tariff change of the form $d t=! e t, e>0$, must raise welfare. However, the more difficult question is what can be said when tariff changes are not equi-proportionate. This is where the concertina rule comes in.

To derive the concertina reform result, disaggregate the tariff vector into $t_{1}$ (a scalar) and $t_{2}$; and assume that $t_{2}$ is fixed. Partitioning the $S$ matrix conformably into its sub-matrices allows (5) to be written as:

$$
\begin{aligned}
\left(1 \& t^{\prime} x_{I}\right) d u & \quad \&\left(t_{1} S_{11} \% t_{2}{ }^{\prime} S_{21}\right) d t_{1} \\
& \quad \&\left[t_{1} \% t_{2}{ }^{\prime} S_{21} S_{11}^{\& 1}\right] S_{11} d t_{1}
\end{aligned}
$$

Now, switch to ad valorem tariffs, $r_{i}=t_{i} / p_{i}$, and make use of the linear homogeneity of $E$ in all prices $\left(p_{0}, p\right)$ :

$$
S_{10} p_{0} \% S_{11} p_{1} \% S_{12} p_{2} \quad ' \quad 0
$$

Transposing and rearranging, this can be written as:

$$
p_{1} S_{11} \quad ' \quad \& p_{0} S_{01} \& p_{2}{ }^{\prime} S_{21}>0
$$

Hence the key equation becomes: 


$$
\left(1 \& t^{\prime} x_{I}\right) d u \quad, \quad \&\left(r_{1} \& \underset{i O ̈ 1}{S} ?_{i l} r_{i}\right) p_{1} S_{11} d t
$$

Note that the summation is over all goods except good 1 but including the numeraire; and that from (9) the weights sum to unity: ${ }_{i l}=! p_{i} S_{i 1}$ $/ p_{1} S_{l 1}, i=0,2,3, \ldots, n, \mathrm{~S} ?{ }_{i l}=1$. Thus, if the tariff on good 1 is reduced $\left(d t_{1}<0\right)$, the right-hand side of $(10)$ is positive provided the tariff rate on good 1 exceeds a weighted average of the tariff rates on all other goods (including the zero 'tariff' on the numeraire). This is where substitutability comes in. The expression in (10) is not a true weighted average unless all the weights are positive. This in turn requires that good 1 be a general equilibrium net substitute for every other good: ? ${ }_{i l}>0$ if and only if $S_{i l}<0$. Hence we finally reach our statement of the concertina rule:

Proposition 1 (The Concertina Rule): If good 1 has the highest tariff rate, a sufficient condition for a reduction in $r_{l}$ to raise welfare is that good 1 is a net substitute for all other goods.

Note that the requirement that good 1 be a net substitute for all other goods is an over-strong sufficient condition. All that is required is that $r_{l}$ $>\mathrm{S} ?_{i l} r_{i}$. For example, complementarities per se (some ? ${ }_{i l}<0$ ) are not a problem. Lowering the highest tariff can only reduce welfare if the good in question is a sufficiently strong complement for some goods that it is also strongly substitutable for some other goods which are subject to high tariffs.

\subsection{Tariff Reform in a Small Open Economy without a Numeraire}

Having reviewed the theory of tariff reform in models with a numeraire, let me now follow the same route in a model which treats all goods symmetrically. This cannot change the substantive results, of course. 
However, it can open the way to misunderstandings.

Since the model is unchanged, its specification is as before, except that I use Greek letters to denote $(n+1)$-by-one vectors which include the numeraire good. Thus, parallelling equations (2) to (4), domestic prices equal world prices plus tariffs:

$$
\mathrm{p} \quad \mathrm{p}^{(\% \mathrm{t},} \quad \mathrm{p}^{\prime}\left\{p_{0}, p\right\} ; \quad \mathrm{p}^{(}{ }^{\prime}\left\{p_{0}^{(}, p^{(}\right\} ; \mathrm{t}^{\prime}\left\{t_{0}, t\right\}
$$

net spending at world prices is zero:

$$
\mathrm{p}^{(} \cdot \mu \quad \mu^{\prime} \quad 0, \quad \quad \mu^{\prime}\left\{m_{0}, m\right\}
$$

and excess demand equals net imports:

$$
E_{\mathrm{p}}(\mathrm{p}, u) \quad, \quad \mu
$$

Totally differentiating yields a slightly different version of equation (5):

$$
\mathrm{p}^{\left({ }^{\prime}\right.} X_{I} d u \quad \text { ' } \quad \mathrm{p}^{\left({ }^{\prime}\right.} S_{\mathrm{pp}} d t
$$

where $X_{I}$ is the $(n+1)$-by-one vector of income derivatives of demand for all goods and $S_{p p}$ is the $(n+1)$-by- $(n+1)$ matrix of price responses and is positive semi-definite. As before, we assume that the coefficient of $d u$, $\mathrm{p}^{*} . X_{I}$ is positive, ${ }^{4}$ so the efficacy of tariff reform hinges on the right-hand side term.

\subsection{Why 'POMPs' are POM}

We are now ready to see why the theorems I presented at the outset may be described as 'potentially misleading'. Consider first what equation (14) says about the effects of uniform reductions in tariffs. Since the excess demand functions are homogeneous of degree one in the vector of 
all prices $\mathrm{p}$, we have $p \$_{p p}=0$. Hence, from (11), the right-hand side of (14) becomes $p^{*} \boldsymbol{S}_{p p} d t=! t \mathbf{S}_{p p} d t$. Hence tariff reductions proportional to initial tariff levels $(d t=! e t)$ must raise welfare. But without any manipulation of (11) it also follows that tariff increases proportional to world prices also raise welfare. This proves POMP 1.

But what exactly does this prove? Consider a tariff reform of the kind specified in the proposition: $d t=d p * !$ et. From (11) this is the same as $d t=d p !(d+e) t$; in words it is the same as raising all tariffs in proportion to domestic prices and then lowering them, by a factor of $d+e$, in proportion to their initial values. The only difficulty with this is that, since raising all tariffs in proportion to domestic prices does not change relative prices, it cannot affect any real magnitudes. In particular it has no effect on welfare! All it amounts to is a rescaling of domestic prices; or put differently, to a change in the numeraire. Hence, the tariff change $d t=d p * !$ et is equivalent to a proportional reduction of tariffs of $(\mathrm{d}+\mathrm{e}) \%$, no more and no less.

The same argument applies to POMP 2. It is technically true that welfare will increase if all tariffs are increased in proportion to world prices. But such a tariff change (of the same form as before with $d>0$ and $e=0$ ) is really a uniform tariff reduction of $\mathrm{d} \%$.

Finally, what about POMP 3? There is no need to prove the concertina rule a second time, since the proof already given makes explicit the role of all $n+1$ goods. Equation (10) also shows that welfare will definitely rise if the tariff rate on good 1 is lower than that on all other goods and good 1 is a net substitute for all of them. However, allowing for a numeraire good leads to a fundamental reinterpretation of this result. By construction, the tariff on the numeraire good itself is zero. Hence, with a numeraire, the lowest tariff is either zero, when it is equal to the tariff on the numeraire itself, or negative, when it amounts to an import subsidy. If the latter, 'raising' the lowest tariff really means reducing a distortion, since the subsidy rate is moved closer to zero. If the former, raising the tariff on the numeraire (which means that it ceases to be a numeraire) is equivalent from homogeneity to lowering tariffs on all other goods. In this case, POMP 3 (like POMPs 1 and 2) is really just a 
restatement of the uniform reduction rule.

In conclusion, I should stress that the papers where these propositions originate make many important contributions other than the ones which I have criticised. ${ }^{5}$ However, I believe that propositions of this sort have done potential harm in appearing to provide a case for tariff increases in distorted small open economies. For example, the World Bank appears to have implemented this advice in many of the structural assistance packages which it has implemented in sub-Saharan Africa. There may be, of course, other reasons why raising some tariffs may be desirable: the desire to avoid a loss of tariff revenue is one possibility. ${ }^{6}$ However, to the extent that the models I have surveyed here are relevant, they do not imply that there is a case for raising tariffs. In the real world, the conditions for the concertina theorem to apply are unlikely to hold in the case where low (but positive) tariffs are raised, since there are typically many goods (such as exports) with zero or even negative trade distortions.

\section{UNILATERAL VERSUS MULTILATERAL REFORM OF TRADE POLICY}

The second area I want to review is that of tariff changes in the world as a whole. Here I want to suggest, not that there are misleading results in the literature, but rather that the fundamental similarity between a number of different results has not been appreciated. These results I therefore label 'ARTs' for 'A following:

ART 1: $\quad$ Proportional reductions in tariffs raise welfare in a small open economy.

ART 2: Given substitutability, concertina reforms of tariffs raise welfare in a small open economy.

ART 3: Proportional reductions in tariffs by all countries are Paretoimproving. 
ART 4: Given substitutability, concertina reforms of tariffs by all countries are Pareto-improving.

ART 5: (Ohyama (1972), Kemp and Wan (1976)) If a group of countries keeps its net external trade fixed, then a Paretoimproving tariff reduction exists.

ARTs 1 and 2 repeat the two small-open-economy results considered in Section 1. I have already noted (as is well known) that they are both special cases of the general expression for welfare-improving tariff changes, (5). ARTs 3 and 4, by contrast, relate to a very different substantive question: When will coordinated tariff changes by a group of countries lead to a welfare improvement for all of them? Finally, ART 5 deals with yet another problem, that of characterising the tariff changes which will ensure a welfare improvement for a customs union. The Ohyama-Kemp-Wan theorem is one of the few clear-cut results in the whole of customs union theory.

As in the last section, I first begin by sketching an analytic framework. Fortunately, much of the necessary work has already been done. Consider a world with many countries, indexed by $j=1, \ldots \mathrm{m}$, each of which can be characterised in just the same way as the small open economy of Section 1 . Thus in each country (indexed by a superscript $j$ ) domestic prices equal world prices plus tariffs:

$$
p^{j} \quad p^{\left(\% t^{j},\right.} \quad j^{\prime} 1, \ldots, m
$$

net domestic spending equals tariff revenue:

$$
E^{j}\left(p^{j}, u^{j}\right) \quad ' \quad t^{j} m^{j}, \quad j^{\prime} 1, \ldots, m
$$

and net imports equal the derivatives of the trade expenditure function:

$$
E_{p}^{j}\left(p^{j}, u^{j}\right) \quad ' \quad m^{j}, \quad j^{1} 1, \ldots, m
$$

This gives $3 m$ equations for the $3 m$ country-specific endogenous variables, 
$\left\{u^{j}\right\},\left\{p^{j}\right\}$ and $\left\{m^{j}\right\}$. The specification of world equilibrium is completed by adding the requirement that world markets must clear:

$$
\mathrm{S}_{k} m^{k} \quad 1 \quad 0
$$

This last equation determines the remaining unknown, $p^{*}$.

Solving the model in full is complicated. Fortunately, we do not need to do this, since all we seek are sufficient conditions for Paretoimproving tariff changes. First, differentiate (15) to (17) as in the small open economy case, and then sum over all countries:

$$
\left.\underset{j}{\mathrm{~S}}\left(1 \& t^{j}\right)_{I} x_{I}^{j}\right) d u_{j} \quad, \quad \& \underset{j}{\mathrm{~S}} t^{j)} S^{j}\left(d p^{\left(\% d t^{j}\right)}\right.
$$

where the notation of Section 1 is extended to the multi-country case in an obvious way. (For example, $S^{j} / ! E_{p p}^{j}$.) Next, differentiate (18):

$$
\mathrm{S}_{k} d m^{k} \quad 1 \quad 0
$$

and use (17) to solve for the change in world prices $d p^{*}$ :

$$
d p^{(} \quad S^{\& 1} \underset{k}{S}\left(x_{I}^{k} d u^{k} \& S^{k} d t^{k}\right)
$$

where $S / S S^{k}$ is the world substitution matrix. Finally, substitute in (19) and collect terms:

$$
\underset{j}{\mathrm{~S}}\left(1 \& T^{j} x_{I}^{j}\right) d u^{j} \quad, \quad \& \underset{j}{\mathrm{~S}} T^{j)} S^{j} d t^{j}
$$

where:

$$
T^{j)} \quad t^{j)} \& \underset{k}{\operatorname{S}} t^{k)} S^{k} S^{\& 1}
$$

This is similar to the small open economy case, as given by (5), except that the 'shadow premia' $T^{j}$ (the differences between home and shadow 
prices)

are not the actual tariffs but their deviations from the worldwide weighted average. The weights are positive definite matrices and sum to the identity matrix: $S S^{k} S^{-1}=I$.

We can now state a single general result which encompasses all five ARTs by means of an assumption and a theorem:

Assumption 1: For every country, the term $\left(1 ! T^{j} \mathbf{N}_{I}^{j}\right)^{! !}$, which equals its shadow price of foreign exchange evaluated at the shadow premia $T^{j}$, is positive.

If Assumption 1 did not hold, it would be possible to obtain a Pareto improvement by lump-sum redistributions of goods (transferring them from countries with negative towards those with positive shadow prices of foreign exchange). I assume that lump-sum international transfers are allowed, since otherwise the problem becomes the much more difficult one of finding conditions for actual rather than merely potential Pareto improvements.

Proposition 2: Given Assumption 1, a necessary and sufficient condition for a Pareto-improving tariff change is that the right-hand side of (22) is positive.

Clearly the proposition follows immediately by inspection of (22). ${ }^{7}$

Proposition 2 is a powerful result. It shows that, as far as efficiency is concerned, international tariff harmonisation is always desirable. Moreover, the number of countries which choose to harmonise their tariffs does not matter. It can be only a single country (as envisaged in ARTs 1 and 2) or all countries in the world (as envisaged in ARTs 3 and 4) or any intermediate group of countries. Note that, if all countries have identical tariff structures, then no further Pareto gains are possible. This is because if the same relative prices prevail in all countries, the remaining common tariffs are equivalent to lump-sum taxes and have no welfare cost.

It is straightforward to show that all five ARTs are corollaries of 
Proposition 2. ARTs 1 and 2 follow trivially. In this context, a small open economy is one whose substitution effects are negligible relative to the world matrix $S: S^{k} S^{! 1}$ is zero. Ignoring tariffs in other countries, the usual uniform reduction and concertina reform results follow as in Section 1. ARTs 3 and 4 also follow straightforwardly. The only qualification is that, to ensure a Pareto improvement with many countries, the theorems must be stated in terms of the shadow premia (23). Thus, the uniform reduction result requires that all tariffs in a given country are reduced in proportion to their shadow premia; and the concertina reform result requires that (given substitutability) the tariff on the good with the highest shadow premium rate (not the highest tariff rate) should be reduced.

Finally, what about ART 5, the Ohyama-Kemp-Wan result? Formally, this is just another corollary of Proposition 2: Pareto-improving reforms of tariffs by all members of a customs union exist, provided their external trade is kept fixed. The interpretation is different because the countries considered comprise only a subset of the world. In ARTs 1 to 4, equation (20) held because there were no other countries in the world; now it holds because the union's common external tariff is adjusted as necessary to ensure that its external trade does not change. Note finally that this version of the Ohyama-Kemp-Wan result is constructive in that it characterises a sequence of internal tariff changes which ensure steady Pareto improvements, rather than merely showing that the abolition of all internal tariffs (given a fixed volume of external trade) is Paretoimproving. Proposition 2 thus extends the existing theory of tariff reform in significant ways as well as encompassing all the earlier theorems.

\section{SUBSIDIES TO HIGH-TECHNOLOGY FIRMS}

The third substantive issue I wish to review is whether governments should support export-oriented high-technology firms. Since such firms typically compete in oligopolistic industries, the tools to examine problems such as this were not available until recently. However, in the 
past 15 years an explosion has taken place in the field of strategic trade policy, applying the insights of modern industrial organisation theory to open economies. The result in my view has been a rich crop of novel theoretical insights but as yet no robust recommendations for policy. The latter point has been made by a number of writers, yet the impression persists that new and important guidelines for policy have been developed. Among the strong and not-so-strong claims which have been made, let me single out three, which I label 'QUARTs' for 'Questionable Assertions Resembling a Theorem':

QUART 1: (The Economist (1996)) Export subsidies should be targeted towards firms in high-technology sectors.

QUART 2: (Brander (1995)) Subsidies to pre-competition variables (such as investment or R\&D) are a more robust recommendation than subsidies to market-period variables (output or price) because the former are more likely to be strategic substitutes.

QUART 3: $\quad$ (The Economist (1996)) The strategic case for subsidies is strengthened by $R \& D$ spillovers.

Once again, to put my claims in context I need to devote a little time to an exposition of the theory. I will concentrate on a canonical model, due to Brander and Spencer (1985) which considers the case for subsidising a single domestic firm which exports all its output (so domestic consumption can be ignored) in competition with a single foreign rival.

\subsection{The Optimal Export Subsidy in a One-Period Duopoly}

QUART 1 resembles the basic result of Brander and Spencer (1985). They showed that if the home and foreign firm engage in a one-shot Cournot game, then an export subsidy is optimal. This result has subsequently been shown to be sensitive to a relaxation of many of the model's assumptions (a fact of which The Economist is clearly aware). 
For example, if firms play a Bertrand price-setting game rather than a Cournot quantity-setting game, then the result is reversed. To see this, consider a general setting where the firms choose an unspecified 'action', which could be either output or price, $a$ for the home firm and $b$ for the foreign firm. (This specification follows Brander (1995).) The home firm's profits equal its net revenue from production and sales, $R(a, b)$, plus the revenue it receives from a subsidy to its action at a rate $s$ :

$$
\mathrm{p}(a, b, s) \quad ' \quad R(a, b) \% s a
$$

This specification encompasses both the Cournot case, where $a$ and $b$ are home and foreign output, $q$ and $q^{*}$, respectively and output is subsidised; and the Bertrand case, where $a$ and $b$ are home and foreign prices, $p$ and $p^{*}$, respectively and price is subsidised. (In Bertrand competition, a subsidy to price has the same efficiency effects and so is equivalent to a tax on the (differentiated) domestic good.) Finally, the home government is assumed to maximise domestic welfare which equals profits less subsidy income:

$$
W(a, b) \quad ' \quad \mathrm{p}(a, b, s) \& s a \quad ' \quad R(a, b)
$$

The basic result is now easily obtained. The home firm's first-order condition is:

$$
\mathrm{p}_{a} \quad R_{a} \% s \quad 1 \quad 0
$$

A symmetric problem faced by the foreign firm leads to a similar condition, though with no subsidy term, since I assume for simplicity that the foreign government is passive: $R_{b}^{*}=0$. The latter condition implicitly defines the foreign firm's reaction firm, which in differential form defines a relationship between the actions of the two firms:

$$
R_{b b}^{(} d b \quad, \quad \& R_{b a}^{(} d a
$$

Here $R_{b b}^{*}$ must be negative from the foreign firm's second-order condition; 
and $R_{b a}^{*}$ is negative if, and only if, the foreign firm's action is a strategic substitute for the home firm's.

Now, totally differentiate the welfare function (25):

$$
d W \quad R_{a} d a \% R_{b} d b
$$

Setting this equal to zero and substituting from (26) and (27) gives the solution for the optimal subsidy:

$$
s \quad \& R_{b} \frac{R_{b a}^{(}}{R_{b b}^{(}}
$$

Recalling that the denominator $R_{b b}^{*}$ is negative in all cases, the BranderSpencer result follows immediately. In Cournot competition goods are substitutes in (inverse) demand, so $R_{b}$ is negative; and $R_{b a}^{*}$ is negative in the normal case where outputs are strategic substitutes. Hence the lefthand side is positive and the optimal policy is an export subsidy. The counter-result of Eaton and Grossman (1986) also drops out. In Bertrand competition, $a$ and $b$ are prices; $R_{b}$ is positive assuming that the goods are substitutes in demand; and $R_{b a}^{*}$ is positive in the normal case where prices are strategic complements. Once again the left-hand side is positive, but now this means that price should be subsidised, which is equivalent to an export tax.

The rationale for government intervention is the same in both Cournot and Bertrand cases. The government is assumed to have the power to commit credibly to a subsidy or tax which affects the environment in which the two firms take their decisions. Optimal policy requires that the government exercise this power to do what the home firm cannot credibly do alone: move the equilibrium to the one which would prevail if the home firm had a first-mover Stackelberg advantage.

Staying with the Cournot case, is QUART 1 not a reasonable restatement of the Brander-Spencer result? I claim that it is not, for there is nothing in the specification of the model which identifies the industry as a high-technology one. The existence of a duopolistic market structure 
requires only that barriers to entry are high. While this may be true of the rivalry between Airbus and Boeing, it is just as true of that between The Economist and Time and Newsweek; between Unilever and Proctor and Gamble in detergents; or between Bowater and Kimberly-Clark in paper tissues. Indeed, in the Brander-Spencer framework the only consideration determining which firms within a group of oligopolistic industries should be subsidised is which ones have the greatest potential for increasing their profits at the expense of their foreign competitors. (See Neary (1994).)

\subsection{Optimal Subsidies to R\&D}

How might the model be extended to focus more specifically on hightechnology industries? An obvious feature of such industries is that production must be preceded by extensive investment in research and product development. This suggests that a two-period framework, in which firms first make such investments and then compete in the product market, should be more relevant to the high-technology case. Following Spencer and Brander (1983) and Neary and Leahy (1996), the model just presented can be extended in this direction.

Suppose that in period 1 the home firm must incur fixed costs $F(k)$ which are increasing in the level of its spending on investment or R\&D, $k$. The payoff to such spending is that it lowers production costs in period 2. This is captured by including $k$ as an argument in the period-2 revenue function, with $R_{k}>0 .{ }^{8}$ Finally, R\&D spending benefits from a subsidy s . Under these assumptions the firm's profit function (24) becomes:

$$
\mathrm{p}(k, a, b, \mathrm{~s}, s) \quad 1 \quad \& F(k) \% R(k, a, b) \% \mathrm{~s} k \% s a
$$

Now, assume that the home government and the two firms engage in a subgame perfect three-stage game. In the first stage the government commits to the two subsidy rates; in the second stage the firms choose their R\&D levels; and in the third stage they choose their actions as before. To solve the model, we work backwards through the stages. In the final stage the firms play a static game just as in Section 3.1 above. The home firm's first-order condition is once again (26). In the second 
stage the firms choose their optimal levels of R\&D, taking account of their effects on the third-stage game. Thus the home firm's choice of R\&D spending takes account both of its direct or 'non-strategic' effect on future profitability as captured by $p_{k}$; and also of its strategic effect in influencing the environment in which the period- 2 game is played. The first-order condition for $R \& D$ is therefore:

$$
\frac{d \mathrm{p}}{d k} \quad \mathrm{p}_{k} \% \mathrm{p}_{b} \frac{d b}{d k} \gamma_{1}, 0
$$

where: $\quad \mathrm{p}_{k}{ }^{\prime} \& F^{\prime} \% R_{k} \% \mathrm{~s}$ and $\mathrm{p}_{b}{ }^{\prime} R_{b}$

The term $d b / d k$ is the effect on the foreign firm's action in the second period which the home firm anticipates will result from an increase in its R\&D. It is calculated by solving the two period- 2 first-order conditions, which is why it is specified as conditional on the foreign firm's choice of $\mathrm{R} \& \mathrm{D}, k^{*}$.

What is the government's optimal policy in this case? As before, with no domestic consumption its welfare function equals profits less subsidy payments:

$$
W(k, a, b) \quad ' \quad \mathrm{p}(k, a, b, \mathrm{~s}, s) \& \mathrm{~s} k \& s a \quad ' \quad R(k, a, b) \& F(k)
$$

Totally differentiating this and substituting from the home firm's firstorder conditions gives:

$$
d W \quad\left[\& \mathrm{~s} \quad \& \mathrm{p}_{b} \frac{d b}{d k}\right] d k \& s d a \% R_{b} d b
$$

The government's problem is straightforward. With two instruments at its disposal (s and $s$ ), it can be viewed as controlling the home firm's choice of $k$ and $a$ directly. As for the foreign firm's choice of $b$, it controls this indirectly by moving the foreign firm along its reaction function. However, unlike in the one-period model of Section 3.1, the relevant 
reaction function is the solution to both the foreign firm's first-order conditions, which are:

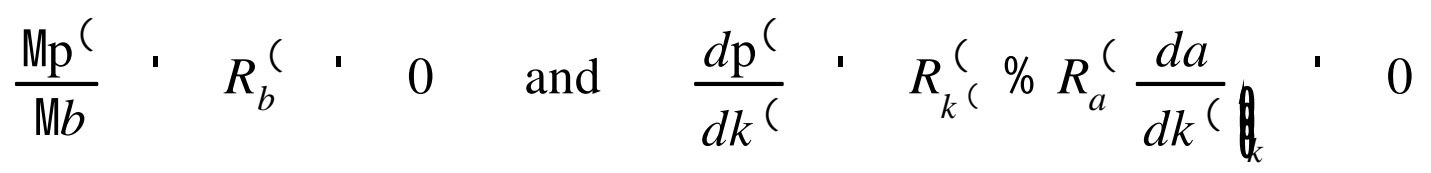

The government solves these conditions to obtain the foreign firm's action as a function of the home firm's two actions:

$$
b \quad ' \quad B(a, k)
$$

Fortunately, since the two firms do not compete directly in the first period, the effect of $k$ on $b$ is of second-order importance and may safely be ignored. ${ }^{9}$ Substituting into (33) yields the optimal subsidies:

$$
\mathrm{s} \quad \& \mathrm{p}_{b} \frac{d b}{d k} \% R_{b} B_{k} \quad \text { and } \quad s \quad R_{b} B_{a}
$$

Except for the term $B_{k}$, which can be ignored, the optimal policies in (36) exhibit a clear division of labour. The period-2 subsidy serves to commit the home firm to the Stackelberg choice of period-2 action, while the R\&D subsidy exactly offsets the strategic effect. Moreover, the signs of these two instruments display exactly the same ambiguity as in the static game. The period-2 export subsidy is positive or negative depending on whether period-2 actions are strategic substitutes or complements, just as in the static case. As for the R\&D subsidy, it has the opposite sign to that of $s$. When period-2 actions are strategic substitutes, the strategic effect is positive. In the terminology of Fudenberg and Tirole (1984), the home firm adopts a 'top dog' strategy, over-investing to give itself an advantage in the period-2 game. The optimal policy is an R\&D tax to 'restrain' the firm. By contrast, when period- 2 actions are strategic complements, the firm adopts a 'puppy dog' strategy of underinvestment. For example, in Bertrand competition, the firm has an incentive to reduce investment in order to raise its rival's price. In this case the optimal policy is an $R \& D$ 
subsidy: the puppy dog should be 'encouraged'

The result for strategic substitutes was obtained by Spencer and Brander (1983); that for strategic complements does not appear to have been noted prior to Neary and Leahy (1996). Taken together, these results suggest that this branch of the theory of economic policy exhibits an aesthetically pleasing unity, but they provide little comfort to policy activism. Contrary to the conjecture of Brander (1995) which I have labelled QUART 2, the ambiguity which plagues the static theory of strategic trade policy is magnified rather than reduced when dynamic behaviour is incorporated.

\subsection{R\&D Spillovers and the Case for Industrial Policy}

The final issue I want to address is the implications for strategic trade policy of allowing R\&D to have non-appropriable spillover effects, so that it reduces the costs of firms other than those of the firm which engages in it. QUART 3 suggests that such spillovers strengthen the strategic trade policy case for supporting innovating firms. However, Leahy and Neary (1996b) show that this inference is not valid. Of course, the presence of positive externalities in itself justifies a subsidy (assuming that the private sector cannot internalise them in Coasian fashion). But this is an old argument, due to Pigou rather than to the theory of strategic trade policy. The relevant question is what additional basis for intervention, if any, is provided by strategic considerations.

The answer turns out to be surprising. When spillovers accrue to firms in the same industry, a Cournot oligopolist has a strategic incentive to reduce its output to reduce the technology transfer to its rivals. ${ }^{10}$ This indeed provides a strategic motive for a government subsidy. But note that the subsidy should be provided even if the firms which benefit from the spillovers are foreign! The point of the subsidy is not to encourage diffusion of new technology but to avoid inefficient underinvestment for strategic reasons. Of course, if the other firms are domestic, it is well known that the strategic case for export subsidies is also weakened. 
What if the firms that benefit from the spillovers are domestic but not in the same industry? Now there is a pure Pigovian basis for subsidising R\&D. But if competition is Cournot, then, from the previous section, there is also a strategic motive for taxing $R \& D$, to counteract the 'top dog' overinvestment behaviour already noted. Thus, the exact type of intervention which is justified is ambiguous and, at least in the Cournot case, the additional strategic arguments work against rather than in favour of R\&D subsidies.

\section{SUMMARY AND CONCLUSION}

In this paper I have reviewed and extended some recent contributions to three areas in the theory of international trade policy. In each case, I have used a simple canonical model to derive the main results in a compact fashion and I have related this model to the principal results in the literature.

In the case of tariff reform in a small open economy, I have drawn attention to some results in the literature which are potentially misleading. In particular, I take issue with suggestions that tariff increases in a small open economy may be desirable. I argue that such recommendations are artifacts of models which do not include a numeraire good. When a numeraire good is included (which is equivalent to saying, when the implications of linear homogeneity in prices are recognised) the case for tariff increases ceases to hold.

Turning to the conditions for Pareto-improving tariff changes I have suggested that a number of results in the literature can be seen as equivalent. A consequence of this perspective is that the same basic principles of tariff reform apply in unilateral, multilateral and customs union contexts. Moreover, I have shown that the Ohyama-Kemp-Wan theorem can be extended beyond an existence result and have shown how the internal tariffs of a customs union can be adjusted to ensure Pareto gains for the members, provided the union's external trade is kept fixed.

Finally, I have reviewed the theory of strategic trade policy and 
shown that it does not provide a secure case for subsidies to hightechnology firms. Indeed, the basic one-period result due to Brander and Spencer merely justifies subsidies to firms in industries with high barriers to entry. These are just as likely to be technologically unsophisticated incumbents in established markets as high-technology firms in growing sectors. The theory can be extended to allow for investments in R\&D prior to the competitive stage, thus more closely approximating the conditions in high-technology industries. But here too the ambiguity which characterises the static theory persists: policies appropriate to firms which compete on quantity are the opposite to those which should be applied to price competitors. Of course, $R \& D$ spillovers provide a clearcut justification for subsidising, though in this case too the optimal subsidy may be reduced or even reversed by strategic considerations. In the light of recent research, the case for subsidising firms in hightechnology sectors is not particularly strong. 


\section{ENDNOTES}

1. The exposition which follows is based on Neary (1995). For extensions to economies with quotas as well as tariffs, see Falvey (1988), Anderson and Neary (1992) and Neary (1995).

2. The full $(n+1)$-by- $(n+1)$ matrix of substitution effects (including those between the numeraire and other goods) is singular and so only positive semi-definite. Provided there is some substitutability between the numeraire good and at least one other good, the $n$-by- $n$ matrix $S$ will be positive definite and it is convenient to assume this henceforward.

3. The inverse of this coefficient, $\left(1 ! t \mathbf{N}_{I}\right)^{! !}$, is known as the 'tariff multiplier' or 'shadow price of foreign exchange.' See Smith (1982) and Neary (1995) for details and references.

4. This is sometimes called the 'Hatta Normality Term' and is easily seen to equal the left-hand side coefficient in (5): $p^{*} \mathbf{X K}_{I}=(p ! t) \mathrm{NK}_{I}=1 ! t \mathbf{N}_{I}$, using homogeneity and setting $t_{0}=0$.

5. Their authors also join a distinguished group whose conclusions have been criticised for failing to recognise the implications of excluding a numeraire good. See, for example, the criticisms of Hotelling (1938) by Frisch (1939); of Dixit (1970) by Sandmo (1974); and of Deaton (1979) by Stern (1986).

6. Though, if this is the case, they should be modelled explicitly. Attempts to do this to date do not provide clear support for increases in low tariffs. See, for example, Falvey (1994) and Anderson (1997).

7. Essentially the same result is obtained by Turunen-Red and Woodland (1991) using Motzkin's theorem of the alternative. However, they do not interpret the shadow premia as deviations from a weighted average and they do not note the general 
applicability of the result as I do here.

8. For example, $R(k, a, b)$ might equal $p . q ! c(k) . q$, where $p . q$ is sales revenue and $c(k)$ is marginal cost, independent of output and decreasing in $k$.

9. The derivatives of $R^{*}$ in (35) do not depend on $k$. Hence $k$ can affect $b$ directly ( $i e$ for given $a$ ) only to the extent that changes in $k$ affect the slope of the home firm's period-2 reaction function and hence affect the term $d a / d k^{*}$ in (35). This effect vanishes, for example, in the case of Cournot competition where marginal costs are independent of output: see Spencer and Brander (1983) and Leahy and Neary (1996a).

10. This incentive has been extensively studied in the closed economy context. See d'Aspremont and Jacquemin (1988) and Leahy and Neary (1997). 


\section{REFERENCES}

Anderson, J.E. (1997), 'Trade reform with a government budget constraint', forthcoming in J. Piggott and A.D. Woodland (eds), International Trade Policy and the Pacific Rim, Macmillan: London.

Anderson, J.E. and J.P. Neary (1992), 'Trade reform with quotas, partial rent retention, and tariffs', Econometrica, 60, pp.57S76.

Brander, J.A. (1995), 'Strategic trade policy', in G. Grossman and K. Rogoff (eds), Handbook of International Economics, Volume III, North-Holland: Amsterdam, pp.1395S1455.

Brander, J.A. and B.J. Spencer (1985), 'Export subsidies and international market share rivalry', Journal of International Economics, 18, pp.83S100.

d'Aspremont, C. and A. Jacquemin (1988), 'Cooperative and noncooperative R\&D in a duopoly with spillovers', American Economic Review, 78, pp.1133S1137.

Deaton, A.S. (1979), 'The distance function in consumer behaviour with applications to index numbers and optimal taxation', Review of Economic Studies, 46, pp.391S405.

Diewert, W.E., A.H. Turunen-Red and A.D. Woodland (1989), 'Productivity and Pareto-improving changes in taxes and tariffs', Review of Economic Studies, 56, pp.199S215.

Dixit, A.K. (1970), 'On the optimum structure of commodity taxes', American Economic Review, 60, pp.295S301.

Eaton, J. and G.M. Grossman (1986), 'Optimal trade and industrial policy 
under oligopoly', Quarterly Journal of Economics, 101, pp.383S406.

Economist, The (1996), 'Economics focus: How to beggar your neighbour', 3 February, p.78.

Falvey, R.E. (1988), 'Tariffs, quotas and piecemeal policy reform', Journal of International Economics, 25, pp.177S1 83.

Falvey, R.E. (1994), 'Revenue enhancing tariff reform', Weltwirtschaftliches Archiv, 130, pp.175S190.

Frisch, R. (1939), 'The Dupuit taxation theorem', Econometrica, 7, pp.145S150.

Fudenberg, D. and J. Tirole (1984), 'The fat-cat effect, the puppy-dog ploy, and the lean and hungry look', American Economic Review, Papers and Proceedings, 74, pp.361S366.

Fukushima, T. and T. Hatta (1989), 'Why not tax uniformly rather than optimally?', Economic Studies Quarterly, 40, pp.220\$238.

Hatta, T. (1977), 'A theory of piecemeal policy recommendations', Review of Economic Studies, 44, pp.1S21.

Hotelling, H. (1938), 'The general welfare in relation to problems of taxation and of railway and utility rates', Econometrica, 6, pp.242S269.

Kemp, M.C. and H.Y. Wan, Jr. (1976), 'An elementary proposition concerning the formation of customs unions', Journal of International Economics, 6, pp.95S97.

Leahy, D. and J.P. Neary (1996a), 'International R\&D rivalry and industrial strategy without government commitment', Review of 
International Economics, 4, pp.322S338.

Leahy, D. and J.P. Neary (1996b), 'R\&D spillovers and the case for industrial policy in an open economy', mimeo.

Leahy, D. and J.P. Neary (1997), 'Public policy towards R\&D in oligopolistic industries', American Economic Review, (forthcoming).

Neary, J.P. (1994), 'Cost asymmetries in international subsidy games: Should governments help winners or losers?', Journal of International Economics, 37, pp.197S218.

Neary, J.P. (1995), 'Trade liberalisation and shadow prices in the presence of tariffs and quotas', International Economic Review, 36, pp.531S554.

Neary, J.P. and D. Leahy (1996), 'Strategic trade and industrial policy towards dynamic oligopolies', mimeo.

Neary, J.P. and A.G. Schweinberger (1986), 'Factor content functions and the theory of international trade', Review of Economic Studies, 53 , pp.421S432.

Ohyama, M. (1972), 'Trade and welfare in general equilibrium', Keio Economic Studies, 9, pp.37S73; reprinted in J.P. Neary (ed): International Trade, Volume I, (1995), International Library of Critical Writings in Economics, Edward Elgar: Cheltenham.

Sandmo, A. (1974), 'A note on the structure of optimal taxation', American Economic Review, 64, pp.701S706.

Smith, A. (1982), 'Some simple results on the gains from trade, from growth and from public production', Journal of International 
Economics, 13, pp.215S230.

Spencer, B.J. and J.A. Brander (1983), 'International R\&D rivalry and industrial strategy', Review of Economic Studies, 50, pp.707S722.

Stern, N.H. (1986), 'A note on commodity taxation: The choice of variable and the Slutsky, Hessian and Antonelli matrices (SHAM)', Review of Economic Studies, 53, pp.293S299.

Turunen-Red, A.H. and A.D. Woodland (1991), 'Strict Pareto-improving multilateral reforms of tariffs', Econometrica, 59, pp.1127S1 152.

Vanek, J. (1964), 'Unilateral trade liberalization and global world income', Quarterly Journal of Economics, 78, pp.139S147. 